\title{
Faktor-Faktor yang Mempengaruhi Jiwa Kewirausahaan Pegawai Bank Perkreditan Rakyat
}

\author{
Mohammad Sofyan \\ Program Studi Ilmu Administrasi Negara, Fakultas Ilmu Administrasi \\ Institut Ilmu Sosial dan Manajemen STIAMI \\ sofyan@stiami.ac.id
}

\begin{abstract}
This study aims to determine the effect of Education and Training, Professionalism, Work Experience, Leadership, and Work Environment on Employee Entrepreneurship. The sample used in this study were 237 respondents from 15 Rural Banks in Bogor Regency and City. Based on the results of the structural equation model, only Professionalism and the Work Environment have a significant effect on the Entrepreneurship of rural banks Employees.

Keywords: Rural Bank, Education and Training, Professionalism, Work Experience, Leadership, Work Environment, Entrepreneurship.
\end{abstract}

\begin{abstract}
Abstrak
Penelitian ini bertujuan untuk mengetahui pengaruh Pendidikan dan Pelatihan, Profesionalisme, Pengalaman Kerja, Kepemimpinan, dan Lingkungan Kerja terhadap Jiwa Kewirausahaan Pegawai. Jumlah sampel yang digunakan dalam penelitian ini adalah sebanyak 237 responden dari 15 Bank Perkreditan Rakyat (BPR) di Kabupaten dan Kota Bogor. Berdasarkan hasil analisis model persamaan struktural (SEM), hanya Profesionalisme dan Lingkungan Kerja yang berpengaruh signifikan terhadap Jiwa Kewirausahaan Pegawai BPR.

Kata kunci: BPR, Pendidikan dan Pelatihan, Profesionalisme, Pengalaman Kerja, Kepemimpinan, Lingkungan Kerja, Jiwa Kewirausahaan.

\begin{tabular}{lcl}
\hline Permalink/DOI & $:$ & http://dx.doi.org/10.32503/jmk.v4i3.586 \\
Cara Mengutip & $: \begin{array}{l}\text { Sofyan, Mohammad. (2019). Faktor-Faktor yang Mempengaruhi } \\
\text { Jiwa Kewirausahaan Pegawai Bank Perkreditan Rakyat. JMK } \\
\end{array}$ & $\begin{array}{l}\text { (Jurnal Manajemen dan Kewirausahaan), 4 (3), 194-204 doi: } \\
\text { http://dx.doi.org/10.32503/jmk.v4i3.586 }\end{array}$ \\
Sejarah Artikel $\quad:$ & $\begin{array}{l}\text { Artikel diterima 14 Agustus 2019; direvisi 26 Agustus 2019; } \\
\text { disetujui 30 Agustus 2019 }\end{array}$ \\
\hline
\end{tabular}
\end{abstract}

Alamat korespondensi :

Institut Ilmu Sosial dan Manajemen STIAMI

Jl. TB. Simatupang No. 47A, Tanjung Barat, Jagakarsa

Jakarta Selatan 12530 


\section{Pendahuluan}

BPR merupakan bank yang memiliki kegiatan usaha terbatas dengan transaksi yang sederhana, meliputi penghimpunan dana dalam bentuk tabungan, deposito berjangka dan penyaluran kredit. Keterbatasan ini diberikan kepada BPR terkait dengan tujuan pelayanan utama kepada Usaha Mikro Kecil dan Menengah (UMKM) serta masyarakat sekitar (Bank Indonesia, 1998).

BPR memiliki cita-cita yang mulia untuk membantu "wong cilik" dari ketergantungannya kepada lintah darat. Dalam sejarahnya, BPR merupakan bagian yang tidak terpisahkan dari gerakan pemberdayaan UMKM di Indonesia karena telah ada sejak abad ke-19 diawali dengan berdirinya Bank Kredit Rakyat dan Lumbung Desa. Pada waktu itu, keberadaannya lebih banyak diperuntukkan kepada para petani, pegawai, dan pekerja lainnya yang terjerat lintah darat.

BPR merupakan lembaga perbankan yang perannya terhadap peningkatan perekonomian wong cilik cukup besar, namun untuk kegiatan operasional BPR dalam prakteknya tidak semua fasilitas yang diberikan pada bank umum ada pada BPR. Fenomena ini menunjukkan bahwa BPR masih belum mendapatkan perhatian pemerintah secara memadai.

Meskipun masih rendahnya fasilitas yang diberikan pemerintah, namun perkembangan kinerja BPR sangat baik dalam lima tahun terakhir sehingga perlu diketahui faktor-faktor apa saja yang membuat BPR mampu tetap bertahan.

BPR memperkuat lapangan pekerjaan di pedesaan karena besarnya kredit yang disalurkan ke sektor perdagangan, rumah makan, dan penginapan sehingga perlu diteliti terobosan-terobosan apa yang dilakukan oleh BPR, yang dalam ini dapat mengarah kepada perlunya mempelajari jiwa kewirausahaan.

Kewirausahaan dan wirausaha merupakan faktor produksi aktif yang dapat menggerakkan dan memanfaatkan sumber daya lainnya seperti sumber daya alam, modal dan teknologi, sehingga dapat menciptakan kekayaan dan kemakmuran, yaitu melalui penciptaan lapangan kerja baru, penghasilan baru, sebagai penggerak kegiatan ekonomi, dan penghasil produk/jasa yang diperlukan masyarakat, karena itu pengembangan kewirausahaan merupakan suatu keharusan di dalam setiap pembangunan.

Banyak faktor psikologis yang membentuk sikap negatif masyarakat, sehingga mereka kurang berminat terhadap profesi wirausaha, antara lain sifat agresif, exspansif, bersaing, egois, tidak jujur, kikir, sumber penghasilan tidak stabil, kurang terhormat, pekerjaan rendah, dan sebagainya. Pandangan semacam ini dianut oleh sebagian orang, sehingga mereka tidak tertarik (Siswoyo, 2009).

Masalah pengangguran menjadi masalah yang sangat serius, dan praktik kewirausahaan sebagai salah satu solusinya. Semakin tinggi pendidikan seseorang, semakin rendah kemandirian dan semangat kewirausahaannya. Sebagian besar lulusan Perguruan Tinggi lebih siap sebagai pencari kerja, daripada sebagai pencipta kerja. Masa depan wirausahawan digambarkan akan terus cemerlang. Pembekalan dan penanaman jiwa entrepreneur pada mahasiswa diharapkan dapat memotivasi mahasiswa menjadi 
wirausahawan yang tangguh, ulet dan mandiri. Kewirausahaan merupakan persoalan penting di dalam perekonomian suatu bangsa yang sedang mambangun. Kemajuan atau kemunduran ekonomi suatu bangsa ditentukan oleh keberadaan dan peranan dari kelompok entrepreneur ini (Siswoyo, 2009).

Salah satu langkah yang diambil untuk mengatasi masalah ini adalah untuk menumbuhkan semangat kewirausahaan mahasiswa.Oleh karena itu penelitian tentang niat kewirausahaan sangat penting karena jika siswa sudah memiliki niat kewirausahaan mahasiswa kemudian akan secara otomatis membuka usaha. Salah satunya meneliti faktor-faktor yang mempengaruhi niat kewirausahaan. Dengan demikian diketahui bahwa faktor-faktor yang mempengaruhi bewirausaha niat yang dimiliki oleh orang lain selain faktor internal, seperti bakat atau sifat bawaan (keturunan), serta kepribadian yang dibentuk oleh faktor-faktor di sekitar (faktor eksternal). Hal ini dibuktikan juga hasil penelitian yang dilakukan saat ini bahwa kepribadian dan lingkungan memiliki pengaruh terhadap niat kewirausahaan.

\section{Tinjauan Pustaka}

Kewirausahaan atau enterpreneurship adalah suatu proses kreativitas dan inovasi yang mempunyai resiko tinggi untuk menghasilkan nilai tambah bagi produk yang bermanfaat bagi masyarakat dan mendatangkan kemakmuran bagi wirausahawan. Kewirausahaan merupakan kemampuan melihat dan menilai peluang bisnis serta kemampuan mengoptimalkan sumberdaya dan mengambil tindakan dan risiko dalam rangka mesukseskan bisnisnya (Siswoyo, 2009). Berdasar definisi ini kewirausahaan itu dapat dipelajari oleh setiap individu yang mempunyai keinginan, dan tidak hanya didominasi individu yang berbakat saja. Kewirausahaan merupakan pilihan yang tepat bagi individu yang tertantang untuk menciptakan kerja, bukan mencari kerja.

Minat berwirausaha dipengaruhi oleh berbagai faktor, yang melibatkan berbagai faktor internal, faktor eksternal dan faktor kontekstual. Faktor internal yang berasal dari dalam diri wirausahawan dapat berupa sifat-sifat personal, sikap, kemauan dan kemampuan individu yang dapat memberi kekuatan individu untuk berwirausaha. Faktor eksternal berasal dari luar diri pelaku entrepreneur yang dapat berupa unsur dari lingkungan sekitar seperti lingkungan keluarga, lingkungan dunia usaha, lingkungan fisik, lingkungan sosial ekonomi dan lainlain (Komsi, 2013). Menurut Suryana (2008) dalam Komsi (2013) menyatakan bahwa faktor yang berasal dari lingkungan di antaranya adalah model peran, peluang, aktivitas, selain itu dipengaruhi juga oleh pesaing, sumber daya, dan kebijakan pemerintah.

Bagi banyak orang keputusan untuk berwirausaha merupakan perilaku dengan keterlibatan yang akan melibatkan: (1) faktor internal (kepribadian, persepsi, motivasi dan pembelajaran (sikap) dan (2) faktor eksternal (lingkungan keluarga, teman dan tetangga) (Tjahjono \& Ardi, 2008). Faktor internal yang berasal dari dalam diri wirausahawan dapat berupa sifat-sifat personal, sikap, kemauan dan kemampuan individu yang dapat memberi 
kekuatan individu untuk berwirausaha. Sedangkan faktor eksternal berasal dari luar diri pelaku entrepreneur yang dapat berupa unsur dari lingkungan sekitar seperti lingkungan keluarga, lingkungan dunia usaha, lingkungan fisik, lingkungan sosial ekonomi dan lainlain (Suharti \& Sirine, 2011).

Pengaruh pendidikan kewirausahaan selama ini telah dipertimbangkan sebagai salah satu faktor penting untuk menumbuh kembangkan hasrat, jiwa dan perilaku berwirausaha di kalangan generasi muda (Indarti \& Rostiani, 2008). Selanjutnya diperlukan adanya pemahaman tentang bagaimana mengembangkan dan mendorong lahirnya wirausaha muda yang potensial sementara mereka berada di bangku kuliah.

Latar belakang pendidikan seseorang terutama yang terkait dengan bidang usaha, seperti bisnis dan manajemen atau ekonomi dipercaya akan mempengaruhi keinginan dan minatnya untuk memulai usaha baru di masa mendatang. Dalam hal ini seorang manajer perlu mengarahkan motivasi dengan menciptakan iklim organisasi melalui pembentukan budaya kerja atau budaya organisasi sehingga para karyawan merasa terpacu untuk bekerja lebih keras agar kinerja yang dicapai juga tinggi. Pemberian motivasi harus diarahkan dengan baik menurut prioritas dan dapat diterima dengan baik oleh karyawan, karena motivasi tidak dapat diberikan untuk setiap karyawan dengan bentuk yang berbedabeda. Salah satu elemen yang bernilai penting dalam sistem manajemen perusahaan selain motivasi kerja kepada para karyawan adalah kepemimpinan. Kepemimpinan adalah suatu proses dimana seseorang dapat menjadi pemimpin melalui aktivitas yang terus menerus sehingga dapat mempengaruhi yang dipimpinnya dalam rangka untuk mencapai tujuan organisasi atau perusahaan (Brahmasari \& Suprayetno, 2008).

Faktor-faktor yang mempengaruhi minat wirausaha pada perempuan tani di Desa Wonokerto meliputi tenaga kerja, skill, lahan, dan jiwa kewirausahaan. Faktor tenaga kerja diukur dengan indikator jumlah keluarga dan rasio kerja. Faktor skill diukur dengan indicator pengenalan tanaman organik, pengetahuan pangan olahan alami, pengetahuan manfaat tanaman salak sebagai olahan, pengetahuan manfaat tanaman garut sebagai bahan olahan, kemudahan membuat pangan olahan salak, dan kemudahan membuat pangan olahan garut. Faktor lahan diukur dengan tiga indikator yaitu lahan tegal, tanaman salak, dan tanaman garut. Sedangkan faktor jiwa kewirausahaan diukur dengan delapan indikator yaitu dorongan, integritas, ketepatan, ketenangan, perkiraan resiko, kesehatan fisik, kebebasan, dan dapat bergaul (Mulyaningsih, Soemarno, Hadiwidjojo, \& Mustajab, 2012).

\section{Metodologi Penelitian}

Penelitian ini merupakan penelitian jenis eksplanatif karena bertujuan untuk meneliti karakteristik peubah dan hubungan antar peubah yang telah ada. Penelitian ini juga bertujuan untuk menjelaskan penyebab dan dampak hubungan. Dari penyelidikannya, penelitian ini merupakan penelitian kausalitas yang menganalisis hubungan sebab akibat antara peubah faktor penentu terbentuknya jiwa kewirausahaan 
pegawai Bank BPR di Kabupaten dan Kota Bogor.

Populasi penelitian ini adalah pegawai Bank BPR di Kabupaten dan Kota Bogor. Penarikan sampel dilakukan dengan teknik probability sampling yang memberikan peluang yang sama bagi setiap anggota populasi yang terpilih. Teknik penarikan sampel yang dipakai adalah random sampling. Dalam teknik ini penarikan sampel dilakukan secara acak sesuai dengan proporsinya. Jumlah sampel minimal ditentukan dengan menggunakan rumus Slovin.

Tabel 1. Jumlah Populasi dan Sampel Pegawai BPR

\begin{tabular}{|c|c|c|c|c|}
\hline No & Nama BPR & Populasi & Sampel & $\%$ \\
\hline (1) & (2) & (3) & (4) & (5) \\
\hline 1 & $\begin{array}{l}\text { BPR Berfasi } \\
\text { Raharja }\end{array}$ & 45 & 7 & 15.56 \\
\hline 2 & $\begin{array}{l}\text { BPR Data } \\
\text { Gita } \\
\text { Mustika }\end{array}$ & 43 & 8 & 18.60 \\
\hline 3 & $\begin{array}{l}\text { BPR Duta } \\
\text { Pakuan } \\
\text { Mandiri } \\
\text { Bogor }\end{array}$ & 50 & 5 & 10.00 \\
\hline 4 & $\begin{array}{l}\text { BPR } \\
\text { Indomitra } \\
\text { Artha } \\
\text { Pertiwi }\end{array}$ & 30 & 5 & 16.67 \\
\hline 5 & $\begin{array}{l}\text { BPR LPK } \\
\text { Leuwiliang }\end{array}$ & 50 & 12 & 24.00 \\
\hline 6 & $\begin{array}{l}\text { BPR LPK } \\
\text { Pancoran } \\
\text { Mas }\end{array}$ & 50 & 5 & 10.00 \\
\hline 7 & $\begin{array}{l}\text { BPR LPK } \\
\text { Parung } \\
\text { Panjang }\end{array}$ & 50 & 13 & 26.00 \\
\hline 8 & $\begin{array}{l}\text { BPR Nature } \\
\text { Primadana } \\
\text { Capital }\end{array}$ & 50 & 12 & 24.00 \\
\hline 9 & $\begin{array}{l}\text { BPR } \\
\text { Parasahabat } \\
\text { Bogor }\end{array}$ & 60 & 54 & 90.00 \\
\hline
\end{tabular}

\begin{tabular}{clccc}
\hline 10 & $\begin{array}{l}\text { BPR Pinang } \\
\text { Artha }\end{array}$ & 50 & 12 & 24.00 \\
\hline 11 & $\begin{array}{l}\text { BPR Rama } \\
\text { Ganda }\end{array}$ & 50 & 8 & 16.00 \\
\hline 12 & $\begin{array}{l}\text { BPR } \\
\text { Sumber } \\
\text { Ekonomi }\end{array}$ & 40 & 7 & 17.50 \\
\hline 13 & $\begin{array}{l}\text { BPR Supra } \\
\text { Wahana } \\
\text { Arta }\end{array}$ & 50 & 28 & 56.00 \\
\hline 14 & $\begin{array}{l}\text { BPRS Al } \\
\text { Salaam } \\
\text { Amal } \\
\text { Salman }\end{array}$ & 50 & 24 & 48.00 \\
\hline 15 & $\begin{array}{l}\text { BPRS } \\
\text { Amanah } \\
\text { Ummah }\end{array}$ & 50 & 37 & 74.00 \\
\hline & Total & 718 & 237 & 33.01 \\
\hline
\end{tabular}

Pemilihan sampel secara acak menggunakan bantuan tabel angka random. Tabel angka random ini dibuat dengan menggunakan fasilitas komputer melalui program Excel. Pengolahan data primer yang telah terkumpul menggunakan beberapa paket program statistik, seperti Lisrel versi 8.8 dan Microsoft Excel 2019.

Data tentang jiwa kewirausahaan pegawai dan faktorfaktor yang mempengaruhinya dikumpulkan dari 15 BPR yang berada di Kabupaten Bogor dan Kota Bogor. Pengumpulan data dilakukan menggunakan instrumen khusus yang dirancang khusus untuk penelitian ini. Dalam penelitian ini, menggunakan 5 peubah laten eksogen, dan 1 peubah laten endogen. Peubah laten eksogen: Pendidikan dan Pelatihan $\left(\xi_{1}\right)$, Profesionalisme $\left(\xi_{2}\right)$, Pengalaman Kerja $(\xi)$, Kepemimpinan $\left(\xi_{4}\right)$, dan Lingkungan Kerja $\left(\xi_{5}\right)$. Sedangkan peubah laten endogen adalah Jiwa Kewirausahaan

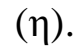




\section{Tabel 2. Definisi Operasional Peubah}

\begin{tabular}{|c|c|c|}
\hline $\begin{array}{l}\text { Peubah } \\
\text { Laten }\end{array}$ & Dimensi & $\begin{array}{c}\text { Skala } \\
\text { Pengukuran }\end{array}$ \\
\hline \multirow{4}{*}{$\begin{array}{l}\text { Pendidikan } \\
\text { dan } \\
\text { Pelatihan } \\
\left(\xi_{1}\right)\end{array}$} & Pendidikan & Ordinal \\
\hline & Komitment & Ordinal \\
\hline & Belajar & \\
\hline & $\begin{array}{l}\text { Berbagi } \\
\text { Pengetahuan }\end{array}$ & Ordinal \\
\hline \multirow[t]{4}{*}{$\begin{array}{l}\text { Profesionali } \\
\text { sme }\left(\xi_{2}\right)\end{array}$} & $\begin{array}{l}\text { Persepsi Terhadap } \\
\text { Profesi }\end{array}$ & Ordinal \\
\hline & $\begin{array}{l}\text { Persepsi Berganti } \\
\text { Persepsi }\end{array}$ & Ordinal \\
\hline & $\begin{array}{l}\text { Persepsi Pelatihan } \\
\text { Profesi }\end{array}$ & Ordinal \\
\hline & $\begin{array}{l}\text { Kebanggan } \\
\text { Terhadap Profesi }\end{array}$ & Ordinal \\
\hline \multirow[t]{5}{*}{$\begin{array}{l}\text { Pengalaman } \\
\text { Kerja }\left(\xi_{3}\right)\end{array}$} & $\begin{array}{l}\text { Komponen } \\
\text { Tujuan }\end{array}$ & Ordinal \\
\hline & $\begin{array}{l}\text { Komponen } \\
\text { Pelanggan }\end{array}$ & Ordinal \\
\hline & Komponen Waktu & Ordinal \\
\hline & Komponen Mutu & Ordinal \\
\hline & Produktivitas & Ordinal \\
\hline \multirow[t]{2}{*}{$\begin{array}{l}\text { Kepemimpi } \\
\text { nan }\left(\xi_{4}\right)\end{array}$} & $\begin{array}{l}\text { Kepemimpinan } \\
\text { Transformasional }\end{array}$ & Ordinal \\
\hline & $\begin{array}{l}\text { Kepemimpinan } \\
\text { Transaksional }\end{array}$ & Ordinal \\
\hline \multirow[t]{3}{*}{$\begin{array}{l}\text { Lingkungan } \\
\text { Kerja }\left(\xi_{5}\right)\end{array}$} & $\begin{array}{l}\text { Komunikasi Dua } \\
\text { Arah }\end{array}$ & Ordinal \\
\hline & $\begin{array}{l}\text { Kualitas } \\
\text { Komunikasi }\end{array}$ & Ordinal \\
\hline & $\begin{array}{l}\text { Kepuasan } \\
\text { Komunikasi }\end{array}$ & Ordinal \\
\hline \multirow{2}{*}{$\begin{array}{l}\text { Jiwa } \\
\text { kewirausah } \\
\text { aan } \\
\text { pegawai }(\eta)\end{array}$} & $\begin{array}{l}\text { Pemanfaatan } \\
\text { Teknologi } \\
\text { Informasi }\end{array}$ & Ordinal \\
\hline & $\begin{array}{l}\text { Keterlibatan SDM } \\
\text { dalam } \\
\text { Managemen } \\
\text { Website }\end{array}$ & Ordinal \\
\hline
\end{tabular}

Model struktural atau structural model dinyatakan sebagai: $\eta_{\mathrm{n}}=\gamma_{\mathrm{mm}} \xi_{\mathrm{m}}+\beta_{\mathrm{nn}} \eta_{\mathrm{n}}+\zeta_{\mathrm{n}}$, asumsi: $\zeta_{\mathrm{n}}$ dengan $\zeta_{\mathrm{m}}$ dan $\eta_{\mathrm{n}}$ tidak berkorelasi. Dengan demikian, persamaan struktural antar peubah laten dinyatakan sebagai berikut:

$$
\begin{aligned}
\eta= & \Upsilon_{11} \xi_{1}+\Upsilon_{12} \xi_{2}+\Upsilon_{13} \xi_{3}+\Upsilon_{14} \xi_{4} \\
& +\Upsilon_{15} \xi_{5}+\zeta_{1}
\end{aligned}
$$

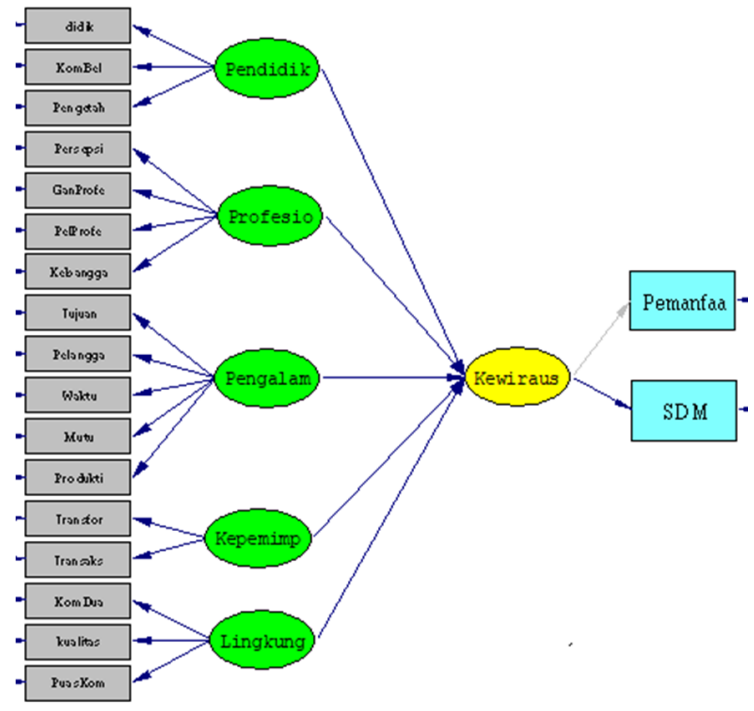

\section{Gambar 1. Paradigma Penelitian}

Hipotesis Statistik :

$\mathrm{H}_{01}: \gamma_{1}=0$ : Tidak ada pengaruh Pendidikan dan Pelatihan terhadap Jiwa Kewirausahaan.

$\mathrm{H}_{1}: \gamma_{1} \neq 0$ : ada pengaruh Pendidikan dan Pelatihan terhadap Jiwa Kewirausahaan.

$\mathrm{H}_{02}: \gamma_{2}=0$ : Tidak ada pengaruh Profesionalisme terhadap Jiwa Kewirausahaan.

$\mathrm{H}_{2}: \gamma_{2} \neq 0$ : ada pengaruh Profesionalisme terhadap Jiwa Kewirausahaan.

$\mathrm{H}_{03}: \gamma_{3}=0$ : Tidak ada pengaruh Pengalaman Kerja terhadap Jiwa Kewirausahaan.

$\mathrm{H}_{3}: \gamma_{3} \neq 0$ : ada pengaruh Pengalaman Kerja terhadap Jiwa Kewirausahaan.

$\mathrm{H}_{04}: \gamma_{4}=0$ : Tidak ada pengaruh Kepemimpinan terhadap Jiwa Kewirausahaan.

$\mathrm{H}_{4}: \gamma_{4} \neq 0$ : ada pengaruh kepemimpinan terhadap Jiwa Kewirausahaan.

$\mathrm{H}_{05}: \gamma_{5}=0$ : Tidak ada pengaruh Lingkungan Kerja terhadap Jiwa Kewirausahaan.

$\mathrm{H}_{5}: \gamma_{5} \neq 0$ : ada pengaruh Lingkungan Kerja terhadap Jiwa Kewirausahaan. 


\section{Hasil}

Tabel 3. Goodness of Fit Index (GOFI)

\begin{tabular}{c|c|c|c}
\hline GOFI & Nilai & $\begin{array}{c}\text { Nilai Standar } \\
\text { untuk } \\
\text { Kecocokan } \\
\text { Baik }\end{array}$ & $\begin{array}{c}\text { Kesimpu } \\
\text { lan }\end{array}$ \\
\hline p value $\chi^{2}$ & 0,058 & $\begin{array}{c}\text { p value }>0,05 \\
\text { RMSEA } \leq \\
0,08\end{array}$ & Good fit \\
\hline RMSEA & 0,029 & Good fit \\
\hline $\begin{array}{c}\text { Standrardized } \\
\text { RMR }\end{array}$ & 0,059 & SRMR $\leq 0,08$ & Good fit \\
\hline NFI & 0,908 & NFI $\geq 0,90$ & Good fit \\
\hline NNFI & 0,985 & NNFI $\geq 0,90$ & Good fit \\
\hline CFI & 0,988 & CFI $\geq 0,90$ & Good fit \\
\hline IFI & 0,988 & IFI $\geq 0,90$ & Good fit \\
\hline GFI & 0,930 & GFI $\geq 0,90$ & Good fit \\
\hline AGFI & 0,906 & AGFI $\geq 0,90$ & Good fit \\
\hline Sumber: Data Penelitian diolah &
\end{tabular}

Berdasarkan hasil output goodness of fit statistics dari software LISREL 8.80 pada Tabel 2, diketahui bahwa seluruh uji menunjukkan good fit. Dengan demikian model penelitian termasuk kategori good fit.

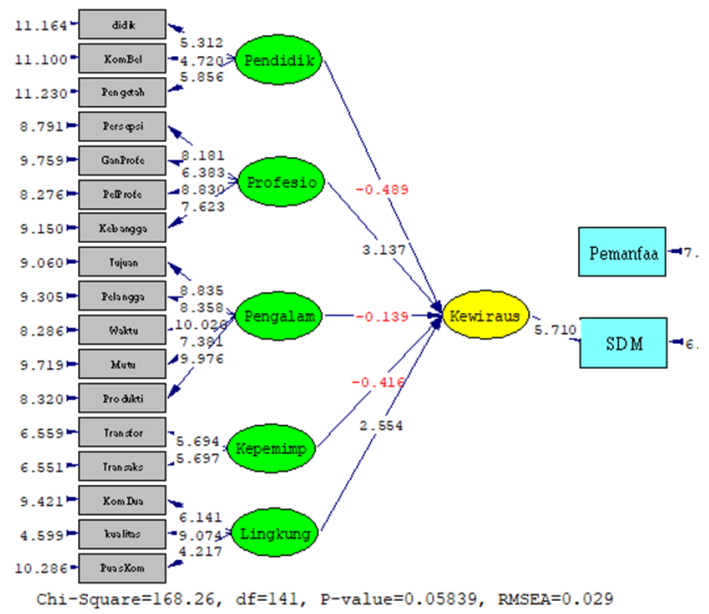

Gambar 2. Hasil Uji T

Tabel 4. Ringkasan Hasil Uji Keseluruhan Model Struktural

\begin{tabular}{lcc}
\hline \multicolumn{1}{c}{ Model } & $\begin{array}{c}\text { Nilai } \\
\mathrm{R}^{2}\end{array}$ & \multicolumn{1}{c}{ Persamaan } \\
& & \\
\hline Jiwa & 0,608 & $=-0,076 *$ pendidikan + \\
Kewirausahaan & & $0,540 *$ profesional - \\
& & $0,020 *$ pengalaman - \\
& & $0,060 *$ kepemimpinan + \\
& & $0,413 *$ lingkungan \\
& & Errorvar. $=0,351$
\end{tabular}

Koefisien determinasi sebesar 0,608 mengindikasikan bahwa variasi Jiwa Kewirausahaan mampu dijelaskan oleh Pendidikan, Profesionalisme, Pengalaman Kerja, Kepemimpinan, dan Lingkungan Kerja sebesar 60,8\%.

\section{Tabel 5. Ringkasan Hasil Uji-T}

\begin{tabular}{|c|c|c|c|c|}
\hline $\begin{array}{l}\mathrm{N} \\
\mathrm{O}\end{array}$ & $\begin{array}{c}\text { Pengaruh Antar } \\
\text { Peubah }\end{array}$ & $\begin{array}{c}\mathrm{t}- \\
\text { observasi }\end{array}$ & $\begin{array}{c}\mathrm{t}- \\
\text { tabel }\end{array}$ & Keputusan \\
\hline 1 & $\begin{array}{l}\text { Pendidikan dan } \\
\text { Pelatihan } \rightarrow \text { Jiwa } \\
\text { Kewirausahaan }\end{array}$ & $-0,489$ & 1,96 & $\begin{array}{c}\text { Tidak } \\
\text { Berpengaruh } \\
\text { Signifikan }\end{array}$ \\
\hline 2 & $\begin{array}{l}\text { Profesionalisme } \\
\rightarrow \text { Jiwa } \\
\text { Kewirausahaan }\end{array}$ & 3,137 & 1,96 & $\begin{array}{c}\text { Berpengaruh } \\
\text { Signifikan }\end{array}$ \\
\hline 3 & $\begin{array}{l}\text { Pengalaman Kerja } \\
\rightarrow \text { Jiwa } \\
\text { Kewirausahaan }\end{array}$ & $-0,139$ & 1,96 & $\begin{array}{c}\text { Tidak } \\
\text { Berpengaruh } \\
\text { Signifikan }\end{array}$ \\
\hline 4 & $\begin{array}{l}\text { Kepemimpinan } \rightarrow \\
\text { Jiwa } \\
\text { Kewirausahaan }\end{array}$ & $-0,416$ & 1,96 & $\begin{array}{c}\text { Tidak } \\
\text { Berpengaruh } \\
\text { Signifikan }\end{array}$ \\
\hline 5 & $\begin{array}{l}\text { Lingkungan Kerja } \\
\rightarrow \text { Jiwa } \\
\text { Kewirausahaan }\end{array}$ & 2,554 & 1,96 & $\begin{array}{c}\text { Berpengaruh } \\
\text { Signifikan }\end{array}$ \\
\hline
\end{tabular}

Berdasarkan Gambar 2 dan tabel 5, diketahui bahwa: (1) Pendidikan dan Pelatihan tidak berpengaruh signifikan terhadap Jiwa Kewirausahaan $\quad(-0,489<1,96)$; (2) Profesionalisme berpengaruh signifikan terhadap Jiwa Kewirausahaan $(3,137>1,96)$; (3) Pengalaman Kerja tidak berpengaruh signifikan terhadap Jiwa Kewirausahaan $\quad(-0,139<1,96)$; (4) Kepemimpinan tidak berpengaruh signifikan terhadap Jiwa Kewirausahaan $\quad(-0,416<1,96)$; (5) Lingkungan Kerja berpengaruh signifikan terhadap Jiwa Kewirausahaan $(2,554>1.96)$.

\section{Pembahasan}

Pendidikan dan Pelatihan harus dijalankan atas dasar prinsip investasi SDM, semakin tinggi kualitas pendidikan dan pelatihan yang diperoleh seseorang, akan semakin produktif orang tersebut. Kualitas 
pendidikan terkait dengan kualitas proses dan produk. Kualitas proses dapat dicapai apabila proses pembelajaran berlangsung secara efektif dan peserta didik dapat menghayati dan menjalani proses pembelajaran tersebut secara bermakna. Kualitas produk tercapai apabila peserta didik menunjukkan tingkat penguasaan yang tinggi terhadap tugas-tugas belajar sesuai dengan kebutuhannya dalam kehidupan dan tuntutan dunia kerja, baik bekerja di kantor maupun bekerja sebagai wirausaha. (Mulyani, 2009). Kajian empiris menunjukkan bahwa Pendidikan dan Pelatihan tidak berpengaruh signifikan terhadap Jiwa Kewirausahaan Pegawai. Hal ini membuktikan bahwa hal-hal yang terkait dengan kesesuaian pendidikan dengan pekerjaan, kesesuaian antara pelatihan dengan pendidikan dan keterkaitan dengan perbankan, bakat yang dimiliki, praktek terhadap materi pelatihan yang diajarkan, dan kemampuan melakukan pekerjaan secara cepat, efisien, lebih baik dan berkualitas, kemampuan menganalisa peluang bisnis, kemampuan beradaptasi dalam mengemban tugas yang lebih tinggi serta menyelesaikannya secara tepat waktu. Di samping itu, juga mencakup kemampuan mempelajari komponen komitmen belajar, kemampuan mempelajari pengetahuan dan meningkatkan keterampilan, serta kemampuan mempelajari hal-hal yang baru belum mampu menumbuhkembangkan jiwa kewirausahaan.

Profesionalisme adalah sebutan yang mengacu kepada sikap mental dalam bentuk komitmen dari para anggota suatu profesi untuk senantiasa mewujudkan dan meningkatkan kualitas profesionalnya. Seorang yang memiliki profesionalisme yang tinggi, akan tercermin dalam sikap mental serta komitmenya terhadap perwujudan dan peningkatan kualitas professional melalui berbagai cara dan strategi. Hal ini selalu mengembangkan dirinya sesuai dengan tuntutan perkembangan zaman sehingga keberadaannya senantiasa memberikan makna profesional (Ambarita, 2013). Kajian empiris membuktikan bahwa Profesionalisme berpengaruh terhadap Jiwa Kewirausahaan Pegawai BPR. Yang berarti bahwa persepsi pelatihan profesi yang mencakup pemahaman tentang tanggung jawab terhadap profesi, dan pemahaman tentang pekerjaan perbankan. Juga mencakup, dimensi tentang kebanggaan terhadap profesi yang mencakup pemahaman tentang profesi perbankan, dan penghargaan masyarakat terhadap profesi, sehingga mampu menumbuhkembangkan jiwa kewirausahaan.

Pengalaman kerja merupakan pedoman seseorang dalam memilih profesi yang tepat bagi dirinya. Orang yang pernah memiliki pengalaman kerja akan lebih selektif dalam memilih profesi yang cocok untuk dirinya (Alimah \& Agustina, 2014). Semakin besar pengalaman kerja yang dimiliki, maka kinerja karyawan akan semakin meningkat. Namun sayangnya dimensi komponen tujuan yang mencakup kemampuan memenuhi misi, mencapai sasaran, dan tuntutan sesuai dengan fungsinya; dimensi komponen pelanggan yang mencakup kemampuan memberikan pelayanan kepada nasabah, kesenangan, dan kepuasan terpenuhinya kebutuhan konsumen; komponen waktu yang mencakup kemampuan mempelajari tentang 
konsekusensi ketepatan waktu, memberikan intruksi kepada bawahan keterlambatan waktu, dan terhadap pekerjaan yang harus penjadwalan kerja; dimensi komponen mutu yang mencakup halhal yang terkait dengan tingkat kesalahan, dan memperbaiki kualitas kerja, dan komponen produktivitas yang mencakup hal-hal yang terkait dengan produktivitas sumber daya manusia, belum mampu menumbuhkan jiwa kewirausahaan.

Pemimpin sesuai dengan perannya, memi liki fungsi utama yang harus dipahami secara mendalam terhadap fungsi yang berhubungan dengan tugas atau bahkan memecahkan masalah. Keutuhan dan kekompakan kelompok merupakan fungsi selanjutnya yang pada umunya sering diabaikan. Leadership style (gaya kemimpinan) yang menggambarkan tentang pola tingkah laku pemimpin dalam proses pengarahan juga sebagai salah satu akan mempengaruhi perkerja yan ada (Sutikno, 2014). Kepemimpinan mencakup dimensi kepemimpinan transformasional yang mencakup tentang kemampuan dan jiwa pemimpin sebagai agent of change, motivator, moralitas, dan inspirator dan dimensi kepemimpinan transaksional yang mencakup hal-hal yang terkait kesetaraan dalam berpendapat dan memberikan ide-ide positif, penilaian terhadap ide-ide yang konstruktif, kestabilan emosi sebagai karakter seorang pemimpin dalam mengelola bawahannya yang memiliki perbedaan tapi saling berkaitan. Unsur lainnya dalam konteks kepemimpinan ini adalah kemampuan menyampaikan kepada bawahan tentang apa yang harus dikerjakan, kemampuan dalam menggunakan partisipasi dari pada bawahan untuk melaksanakan pekerjaan dengan baik, kemampuan dikerjakan. Pemimpin yang baik juga harus mempunyai sifat yang bersahabat dengan bawahannya, dapat memberikan dorongan kepada bawahan supaya bawahan bersemangat bekerja, memberikan kesempatan untuk mendiskusikan suatu pekerjaan, mampu menggunakan hukuman/peringatan untuk mengontrol pegawai, kemampuan memperhatikan konflik antar pegawai, serta memberikan perhatian khusus terhadap pegawai yang kurang sukses dalam menjalankan tugas yang di berikan. Namun sayangnya kepemimpinan belum menumbuhkembangkan kewirausahaan pegawai BPR.

Lingkungan Kerja dalam konteks BPR diukur dengan pendekatan kualitatif yaitu dengan menanyakan hal yang bersifat persepsi baik yang bersifat komunikasi, dan keadilan yang dirasakan dalam menerima penghargaan dalam bentuk upah atau apresiasi lainnya. Dimensi ini terdiri dari sembilan dimensi yaitu dimensi frekuensi komunikasi yang mencakup kontinyunitas komunikasi yang terjalin; dimensi komunikasi informal yang mencakup tentang media komunikasi yang digunakan; dimensi komunikasi langsung yang mencakup hal-hal yang terkait dengan penjelasan pekerjaan dan tugas. Dimensi berikutnya adalah dimensi komunikasi dua arah yang mencakup pemahaman komunikasi yang efektif terkait dengan informasi persaingan, kondisi pelanggan dan kondisi pasar. Dimensi kualitas komunikasi yang mencakup pemahaman tentang kualitas komunikasi yaitu kecocokan, keakuratan, memadai dan lengkap. 
Dimensi kepuasan komunikasi yang mencakup pemahaman tentang tingkat kepuasan hasil komunikasi yang dilakukan. Dimensi kepuasan kerja yang terkait dengan posisi pekerjaan dihargai, menarik dan memuaskan. Dimensi keadilan internal yang mencakup persepsi personal terhadap keadilan gaji, tunjangan, bonus, insentif, dan pengakuan prestasi kerja. Dimensi keadilan eksternal yang mencakup persepsi personal studi komparatif perusahaan lain yang terkait dengan gaji, tunjangan, bonus, insentif dan penghargaan. Hasil kajian empiris membuktikan bahwa lingkungan kerja BPR di Kotadan Kabupaten Bogor mampu menumbuhkembangkan jiwa kewirausahaan pegawai.

\section{Simpulan}

Kajian empiris di atas menunjukkan bahwa dari lima peubah laten eksogen yang diteliti, hanya dua peubah yaitu Profesionalisme dan Lingkungan Kerja yang berpengaruh signifikan terhadap Jiwa Kewirausahaa. Ini berarti peningkatan Jiwa Kewirausahaan Pegawai pada Bank Perkreditan Rakyat (BPR) utamanya dipengaruhi oleh Profesionalisme dan Lingkungan Kerja.

Sayangnya faktor Kepemimpinan belum merupakan peubah yang mampu meningkatkan pengembangan BPR, karena pengaruhnya terhadap Jiwa Kewirausahaan Pegawai adalah negatif. Hal ini dapat dimengerti mengingat sebagian besar responden dalam survei ini adalah staf administrasi. Disamping itu, kepemimpinan yang negatif terhadap jiwa kewirausahaan karena BPR merupakan bank yang diduduki oleh mayoritas bukan pendidikan sarjana yang mengakibatkan peran SDM yang ada masih sangat dipengaruhi oleh keterbatasan SDM itu sendiri.

\section{Daftar Pustaka}

Alimah, N., \& Agustina, L. (2014). Faktor-Faktor Mempengaruhi yang Mahasiswa Minat Pendidikan (PPA). Accounting Analysis Journal, 3(1), 361-369. https://doi.org/ISSN 2252-6765

Ambarita, B. (2013). Profesionalisme, Esensi Kepemimpinan, dan Manajemen Organisasi. GENERASI KAMPUS, 6(2), 116. Retrieved from https://jurnal.unimed.ac.id/2012/ index.php/gk/article/view/7084/6 066

Bank Indonesia. (1998). UndangUndang Nomor 10 Tahun 1998 Tentang Perbankan. UndangUndang No. 10 Tahun 1998 Tentang Perbankan. https://doi.org/10.1007/s13398014-0173-7.2

Brahmasari, I. A., \& Suprayetno, A. (2008). Pengaruh Motivasi Kerja, Kepemimpinan dan Budaya Organisasi Terhadap Kepuasan Kerja Karyawan serta Dampaknya pada Kinerja Perusahaan (Studi kasus pada PT. Pei Hai International Wiratama Indonesia). Jurnal Manajemen Dan Kewirausahaan, 10(2), 124-135. Retrieved from http://jurnalmanajemen.petra.ac.i d/index.php/man/article/view/17 039/17003

Indarti, N., \& Rostiani, R. (2008). Intensi Kewirausahaan Mahasiswa: Studi Perbandingan 
Antara Indonesia, Jepang dan Norwegia. Jurnal Ekonomi \& Bisnis Indonesia (Fakultas Ekonomi Dan Bisnis Universitas Gadjah Mada), 23(4), 371-383. https://doi.org/10.22146/jieb.631 6

Komsi, K. (2013). Analisis Pengaruh Faktor Eksternal dan Internal terhadap Minat Berwirausaha. Proceeding PESAT (Psikologi, Ekonomi, Sastra, Arsitektur \& Teknik Sipil), 1-8. Retrieved from

http://ejournal.gunadarma.ac.id/i ndex.php/pesat/article/download/ 801/713

Mulyani, E. (2009). Strategi Menumbuhkan Sikap Dan Perilaku Wirausaha Melalui Pembelajaran Kooperatif Yang Berwawasan Kewirausahaan. Jurnal Ekonomi Dan Pendidikan, 6(2), 116-132. https://doi.org/10.21831/jep.v6i2 .580

Mulyaningsih, S., Soemarno, Hadiwidjojo, D., \& Mustajab, M. M. (2012). Faktor-Faktor Yang Mempengharuhi Minat Wirausaha Pengolahan Pangan Organik Pada Perempuan Tani di Desa Wonokerto, Bantur, Malang. WACANA Jurnal Sosial Humaniora, 15(2), 12-18. Retrieved from https://wacana.ub.ac.id/index.ph $\mathrm{p} /$ wacana/article/view/265/223

Siswoyo, B. B. (2009). Pengembangan Jiwa Kewirausahaan di Kalangan Dosen dan Mahasiswa. Jurnal Ekonomi Bisnis, 2(14), 114-123. Retrieved from http://fe.um.ac.id/wpcontent/uploads/2009/10/bamban g_banu4.pdf

Suharti, L., \& Sirine, H. (2011).
Faktor-Faktor yang Berpengaruh terhadap Niat Kewirausahaan (Entrepreneurial Intention ) (Studi terhadap Mahasiswa Universitas Kristen Satya Wacana , Salatiga). Jurnal Manajemen Dan Kewirausahaan, 13(2), 124-134. https://doi.org/10.9744/jmk.13.2. 124-134

Sutikno, S. (2014). Pemimpin dan kepemimpinan (1st ed.). Lombok: Holistica.

Tjahjono, H. K., \& Ardi, H. (2008). Kajian Niat Mahasiswa Manajemen Universitas Muhammadiyah Yogyakarta Untuk Menjadi Wirausaha. Utilitas Jurnal Manajemen Dan Bisnis, 16(1), 1-23. Retrieved from

http://repository.umy.ac.id/handl e/123456789/2133 